\title{
VARIASI BAHASA DALAM KOLOM MELA KOMENTAR SURAT KABAR RAKYAT BENGKULU
}

\author{
Hotlan Siboro, Dian Eka Chandra, dan Ngudining Rahayu \\ Program Studi Pendidikan Bahasa dan Sastra Indonesia \\ Jurusan Pendidikan Bahasa dan Seni \\ FKIP Universitas Bengkulu \\ hotlansiboro813@yahoo.co.id
}

\begin{abstract}
Abstrak
Tujuan dari penelitian ini adalah untuk mendeskripsikan variasi bahasa lisan pada kolom Mela Komentar surat kabar Rakyat Bengkulu dan variasi bahasa dalam kolom Mela Komentar surat kabar Rakyat Bengkulu dilihat dari segi keformalannya. Penelitian ini menggunakan rancangan penelitian deskriptif dengan menggunakan teknik dokumentasi sebagai alat pengumpulan data. Untuk analisis data digunakan langkah-langkah berikut, (1) membaca secara teliti, (2) memberi kode pada setiap data yang diperoleh, (3) mentabulasi data yang digunakan untuk menggambarkan penggunaan bahasa, (4) menganalisis data penggunaan bahasa lisan ditinjau dari tingkat keformalannya, (5) mengklasifikasikan hasil analisis data, (6) mensintesiskan hasil klasifikasi, (7) menyimpulkan. Dari hasil penelitian yang dilakukan diperoleh gambaran bahwa variasi bahasa dalam kolom Mela Komentar digunakan bahasa lisan baku dan bahasa lisan tidak baku. Variasi bahasa dilihat dari segi keformalannya digunakan ragam santai dan ragam akrab. Penanda penggunaan bahasa lisan baku dilihat pada penggunaan kosa kata dan diksi bahasa Indonesia dan tidak ada unsur bahasa daerah. Penanda penggunaan bahasa lisan tidak baku dilihat pada penggunaan kata tidak baku, penggunaan bahasa daerah/asing, penggunaan bahasa gaul dan adanya pernyataan ekspresi. Penanda penggunaan ragam santai dilihat pada penggunaan bahasa daerah/asing, penggunaan kata tidak baku, penggunaan bahasa gaul dan pernyataan ekspresi. Penggunaan ragam akrab dilihat pada penggunaan kata sapaan, penggunaan bahasa daerah/asing dan istilah khas. Kesimpulan; Variasi bahasa dalam kolom Mela Komentar edisi 26 Oktober sampai 24 November 2016 sebanyak 30 topik dengan 265 ujaran, dapat disimpulkan sebanyak 38 ujaran menggunakan bahasa lisan baku dan 227 menggunakan bahasa lisan tidak baku. Variasi bahasa dilihat dari segi keformalannya menggunakan ragam santai dan ragam akrab.
\end{abstract}

Kata kunci: variasi bahasa, kolom mela komentar, surat kabar Rakyat Bengkulu

\begin{abstract}
The purpose of this study is to describe the variation of spoken language in the column Mela Bengkulu People's newspaper commentary and language variations in the column Mela Bengkulu People's newspaper comments in terms of formality. This research uses descriptive research design and using documentation technique as data collection tool. For data analysis, the following steps are used: (1) read carefully, (2) code every data obtained, (3) tabulate data used to describe language usage, (4) analyze data of spoken language in terms of level (5) classify the results of data analysis, (6) synthesize the results of classification, (7) conclude. From the result of the research, it is found that the variation of language in Mela Comments column used standard oral language and non standard oral language. Language variations seen in terms of formality are used diverse casual and familiar variety. The marker
\end{abstract}


of standard oral spoken language is seen in the use of Indonesian vocabulary and diction and no regional language elements. Markers of oral spoken language use are not seen in nonstandard word usage, regional/foreign language usage, slang usage and presence of expression statements. Markers of casual usage are seen in the use of regional/foreign languages, the use of non-standard words, the use of slang and expressions. The use of familiar varieties is seen in the use of the word hello, the use of regional/foreign languages and typical terms. Conclusion; Language variations in the October 26 to 24 November 2016 edition of Mela Comments column of 26 topics with 265 speeches, can be summarized by 38 speeches using standard oral language and 227 using non-standard spoken language. Language variations are viewed in terms of its formality using a variety of casual and diverse.

\section{Keywords: language variation, mela komentar column, Rakyat Bengkulu newspaper}

\section{PENDAHULUAN}

Pengaplikasian bahasa sebagai alat komunikasi adalah penggunaan bahasa jurnalistik dalam surat kabar. Bahasa jurnalistik merupakan salah satu ragam yang dipakai dalam surat kabar yang dibaca oleh masyarakat yang sangat heterogen. Bahasa ini dipakai dalam semua media masa baik audio, visual maupun media cetak. Wijaya dan Rohmadi (2013: 165) mengatakan bahwa media massa yang mempunyai frekuensi kemunculannya tinggi dan tersebar luas di masyarakat adalah media cetak. Hal ini dikarenakan beragamnya media massa cetak yang tersebar di masyarakat, seperti koran, majalah dan tabloid.

Wujud nyata bahasa sebagai alat komunikasi dalam surat kabar dipakai dalam penulisan headline, reportase, artikel, opini, rubrik, kolom, tajuk rencana atau editorial, surat pembaca, dan tulisan pojok sebagai wadah masyarakat untuk menyampaikan pendapat, kritikan serta harapan dari masyarakat. Masyarakat yang heterogen akan menghasilkan kevariasian bahasa dalam komunikasi. Bentuk komunikasi masyarakat dalam surat kabar akan menghasikan variasi bahasa dari segi pemakaian dan segi keformalan (Chaer dan Agustina, 2010: 62-73).

Surat kabar akan memberikan informasi yang ditunggu oleh masyarakat setiap hari. Surat kabar tidak hanya dibutuhkan oleh kalangan tertentu saja, tetapi oleh seluruh lapisan masyarakat untuk menambah informasi masyarakat. Surat kabar tidak hanya memberikan informasi berita yang aktual kepada pembaca, tetapi surat kabar pun memberikan sarana bagi pembaca untuk menyampaikan pendapat, ide, gagasan, dan keinginan. Salah satu surat kabar di provinsi Bengkulu adalah surat kabarRakyat Bengkulu.

Rakyat Bengkulu adalah surat kabar yang ada di Provinsi Bengkulu dan sudah berusia 15 tahun. Rakyat Bengkulu setiap harinya terbitnya dari 1-23 halaman. Rakyat Bengkulu menjadi salah satu surat kabar terkemuka dan paling banyak dibaca oleh masyarakat di Bengkulu karena menjadi satu-satunya surat kabar dengan jangkauan yang luas, Rakyat Bengkulu menjangkau semua daerah dan kota di Provinsi Bengkulu. Pembaca dapat menuangkan pendapat, ide, gagasan, dan keinginan dalam sebuah kolom yang muncul setiap harinya dalam surat kabarRakyat Bengkulu.

Surat kabar Rakyat Bengkulu terdiri dari berbagai macam kolom. Adapun kolom pada surat kabar Rakyat Bengkulu yaitu Lapor Cik dan Mela Komentar. Pembaca bisa memberikan pendapat, opini atau gagasan pada kolom di surat kabar 
Rakyat Bengkulu. Kolom ini dapat ditemui di halaman kedua dengan nama Kolom Mela Kometar. Kolom Mela Kometar adalah salah satu wahana penyampaian pendapat, ide, gagasan dan keinginankeinginan pembaca surat kabar.

Mela Komentar berasal dari dua kata, yaitu mela dan komentar. Kata mela merupakan bahasa lembak Bengkulu yang arti katanya mengajak atau ayolah. Kata Komentar merupakan bahasa Indonesia yang artinya tanggapan atas berita. Kolom mela komentar mengajak masyarakat untuk ikut memberikan pendapat, ide atau gagasan terhadap topik yang sedang dibicarakan. Kolom mela komentar dalam surat kabar Rakyat Bengkulu terbit setiap hari.

Kolom Mela Kometar memiliki ciri khas dari kolom yang lain pada surat kabar Rakyat Bengkulu. Kolom Mela Kometar akan menerbitkan komentar pembaca terhadap suatu topik berita yang sedang panas. Kolom ini merupakan wadah komunikasi masyarakat untuk menyampaikan pendapatnya tentang berbagai permasalahan yang aktual berasal dari berita lokal di Provinsi Bengkulu maupun berita nasional. Berikut contoh topik dan ujaran dalam kolom Mela Komentar.

\section{Data 08}

(Lampiran Gambar 08/RB/02112016/).

Rencana Pemerintah Provinsi Bengkulu menaikkan gaji tenaga honorer tahun 2017, batal. Tenaga honorer yang diperpanjang kontraknya diberikan diskon jam kerja. Dalam seminggu hanya bekerja tiga hari. (Topik 8)

\section{Kalimat:}

(57) Tigo hari di dinas sini, tigo hari di dinas sano, dak ketahuan, kan enak gajinyo duo cik, hahah (Apri)

(60) Jadilah disyukuri daripado idak samo sekali. (Dani)

Kalimat (57) kata tigo, sano, dak, gajinyo dan duo menggunakan unsur bahasa daerah. Penggunaan kata tigo, sano, dak, gajinyo dan duo sebagaimana dalam bahasa Indonesia merupakan kata tiga, sana, tidak, gajinya dan dua. Adanya penggunaan unsur bahasa daerah pada kalimat (57) menjadikan ad

anya variasi bahasa dalam kolom Mela Komentar..

Kalimat (60) kata daripado, idak dan samo digunakan unsur bahasa daerah. Penggunaan kata daripado, idak dan samo sebagaimana dalam bahasa Indonesia merupakan kata daripada, tidak dan sama. Adanya penggunaan unsur bahasa daerah pada kalimat (60) menjadikan adanya variasi bahasa dalam kolom Mela Komentar.

Penggunaan kata sapaan pada kalimat (57) kata cik menandakan bahwa situasi komunikasi dalam keadaan santai dan akrab. Adanya penggunaan kata sapaan pada kalimat (57) menjadikan adanya variasi bahasa dalam kolom Mela Komentar dilihat dari segi keformalannya.

Berdasarkan latar belakang tersebut maka dirumuskan masalah secara umum bagaimanakah variasi bahasa dalam kolom "Mela Komentar" pada surat kabar Rakyat Bengkulu? Penelitian ini bertujuan untuk mendeskripsikan variasi bahasa dalam kolom Mela Komentar surat kabar Rakyat Bengkulu. Secara khusus mendeskripsikan variasi bahasa lisan pada kolom Mela Komentar surat kabar Rakyat Bengkulu dan variasi bahasa dalam kolom Mela Komentar surat kabar Rakyat Bengkulu dilihat dari segi keformalannya.

\section{METODE}

Penelitian ini menggunakan rancangan penelitian deskriptif dengan menggunakan teknik dokumentasi sebagai alat pengumpulan data.

Sumber Data dalam penelitian ini adalah Surat kabarRakyat Bengkulu Data edisi 26 Oktober sampai 24 November 2016. Data dalam penelitian ini adalah 
ujaran masyarakat yang terepresentasikan pada kolom Mela Komentar edisi 26 Oktober sampai 24 November 2016.

Analisis data menggunakan langkahlangkah berikut, (1) membaca secara teliti, (2) memberi kode pada setiap data yang diperoleh, (3) mentabulasi data yang digunakan untuk menggambarkan penggunaan bahasa, (4) menganalisis data penggunaan bahasa lisan ditinjau dari tingkat keformalannya, mengklasifikasikan hasil analisis data, (6) mensintesiskan hasil klasifikasi data, (7) menyimpulkan.

\section{HASIL DAN PEMBAHASAN}

Berdasarkan hasil penelitian mengenai variasi bahasa dalam kolom Mela Komentar surat kabar Rakyat Bengkulu, penulis akan membahas variasi bahasa yang digunakan masyarakat dalam memberikan ide, pendapat dan gagasan terhadap sebuah topik. Adapun variasi bahasa yang digunakan adalah sebagai berikut.

1. Variasi bahasa lisan dalam kolom Mela Komentar surat kabar Rakyat Bengkulu.

a. Variasi Bahasa Lisan Baku

Variasi bahasa lisan baku dalam kolom Mela Komentar surat kabar Rakyat Bengkulu dapat dilihat dari penggunaan bentuk kata yang digunakan masyarakat dalam memberikan respond terhadap topik yang dibicarakan.

a) Penggunaan Bentuk Kata.

Berikut ini adalah data penggunaan variasi bahasa lisan dilihat dari penggunaan bentuk kata. Penggunaan bentuk kata dapat membedakan antara variasi bahasa lisan dan variasi bahasa tulis.

Data 02

(Tabel 2/Data 02/RB/27102016/)

Hampir dipastikan terhitung 1 Januari 2017, gaji honorer akan dianggarkan minimal sesuai Upah Minimum Provinsi (UMP). Seperti diketahui UMP tahun 2017 yang bakal ditetapkan gubernur Rp 1,7 juta. (Topik 02)

Kalimat:

(13) Ya semoga mereka kerjanya lebih jelas dan baik (Azhari)

Kalimat (13) memberikan respond sebuah harapan agar pekerja honorer bekerja lebih jelas dan baik. Makna harapan itu nampak pada kata ya semoga. Kata ya menandakan bahwa penutur mengerti topik pembicaraan. Kata ya merupakan penanda ragam bahasa lisan yang digunakan dalam kehidupan seharihari.

Penggunaan kata.

Ragam Bahasa lisan: $Y a$ semoga mereka kerjanya lebih jelas dan baik. (Azhari)

Ragam Bahasa tulis: Saya berharap semoga mereka bekerja lebih jelas dan baik. (Azhari)

Dalam ragam bahasa tulis penggunaan kata ya dan kerjanya berbeda dengan ragam bahasa lisan. Dalam bahasa tulis kata ya dan semoga menjadi kata saya berharap dan bekerja. Sehingga ragam bahasa tulis menjadi saya berharap semoga mereka bekerja lebih jelas dan baik. Saya berharap menggantikan penggunaan kata ya dan bekerja menggantikan kata kerjanya.

b) Pelesapan Unsur Kata.

Berikut ini adalah data penggunaan bahasa lisan dilihat dari pelesapan unsur kata.

\section{Data 02}

(Tabel 2/Data 02/RB/27102016/)

Hampir dipastikan terhitung 1 Januari 2017, gaji honorer akan dianggarkan minimal sesuai Upah Minimum Provinsi (UMP). Seperti diketahui UMP tahun 2017 yang bakal ditetapkan gubernur Rp 1,7 juta. (Topik 02)

Kalimat:

(10) Sip semoga terealisasi (Mak Fahri) 
Kalimat (10) memberikan respond sebuah harapan agar kenaikan Upah Minimun Provinsi (UMP) segera menjadi kenyataan. Makna harapan itu nampak pada kata sip semoga. Kata sip menandakan bahwa penutur mengerti topik pembicaraan. Kata sip merupakan penanda bahasa lisan yang digunakan dalam kehidupan sehari-hari.

Penggunaan kata.

Ragam Bahasa lisan:Sip semoga terealisasi (Mak Fahri)

Ragam Bahasa tulis:Saya berharap semoga terealisasi (Mak Fahri)

Dalam ragam bahasa tulis penggunaan kata sip berbeda dengan ragam bahasa lisan. Dalam ragam bahasa tulis kata sip menjadi kata saya berharap. Sehingga ragam bahasa tulis menjadi saya berharap semoga terealisasi. Saya berharap menggantikan penggunaan kata sip.

c) Unsur-unsur gramatikal tidak selalu dinyatakan.

Di dalam bahasa lisan unsur-unsur fungsi gramatikal seperti subjek, predikat dan objek tidak selalu dinyatakan. Unsur-unsur itu kadangkadang dapat ditinggalkan. Bahasa tulis perlu lebih terang dan lebih lengkap dari bahasa lisan. Berikut adalah data unsur-unsur gramatikal tidak selalu dinyatakan.

\section{Data 05}

\section{Tabel 2/Data 05/RB/30102016/:}

Korban penipuan SN, ibu artis ibukota asal Bengkulu, terus bertambah. Sebelumnya, SN dilaporkan dua korban, Agustina dan Yanti karena uang mereka Rp 350 juta tidak dikembalikan. Kali ini korbannya adalah Wati (54) istri pengacara kondang, Drs. Ahmad Nurdin, S.H. Cak mano ini cik. (Topik 05)

Kalimat:

(35) Semoga bisa diproses sesuai dengan hukum yang berlaku (Juju)
Kalimat (35) memberikan respond sebuah harapan agar pelaku penipuan dapat diproses sesuai dengan hukum yang berlaku. Makna harapan itu nampak pada kata semoga. Kata semoga menandakan bahwa penutur mengerti topik pembicaraan. Kata semoga merupakan penanda bahasa lisan yang digunakan dalam kehidupan sehari-hari.

Penggunaan unsur-unsur gramatikal tidak selalu dinyatakan

Ragam Bahasa lisan:Semoga bisa diproses sesuai dengan hukum yang berlaku (Juju)

Ragam Bahasa tulis: Saya berharap semoga bisa diproses sesuai dengan hukum yang berlaku (Juju)

Dalam ragam bahasa tulis adanya penambahan subjek pada kata saya. Penambahan predikat pada kata berharap. Dalam ragam bahasa lisan unsur-unsur fungsi gramatikal seperti subjek, predikat dan objek tidak selalu dinyatakan. Pada kalimat (35) unsur-unsur gramatikal yang tidak dinyatakan atau dihilangkan adalah unsur subjek dan predikat. Dalam ragam bahasa tulis unsur-unsur gramatikal harus dinyatakan terutama subjek dan predikat.

Kalimat yang lengkap adalah:

Ragam Bahasa tulis: Saya berharap semoga bisa diproses sesuai dengan hukum yang berlaku (Juju)

d) Penggunaan Struktur Kalimat

Penggunaan struktur kalimat berhubungan dengan pola kalimat $\mathrm{S} P$ O K Pel. Berikut ini adalah data penggunaan bahasa lisan dilihat dari penggunaan struktur kalimat.

Tabel 2/Data 04/RB/29102016/:

Kursi Ketua DPRD Rejang Lebong (RL) akan segera berganti tuan. Itu lantaran ketua DPRD RL saat ini Abu Bakar, SH dari Partai Gerindra, mendekam di Lapas Bentiring akibat kasus dugaan korupsi beras keluarga miskin (raskin). Kepastian dicopotnya Abu Bakar dari kursi ketua DPRD RL, disampaikan ketua DPD Partai Gerindra Provinsi 
Bengkulu Susi Marleny Bachsin, SE, MM. (Topik 04)

\section{Kalimat:}

(29) Kursi panas, siapa cepat dia dapat. (Wibowo)

Kalimat (29) kalimatnya kurang terstruktur. Subjek dan predikat digunakan diakhir kalimat, yaitu kata dia dan dapat. Dia menduduki sebagai subjek dan dapat menduduki sebagi predikat. Objek digunakan pada awal kalimat, yaitu kursi panas. Penggunaan kalimat yang kurang terstruktur pada kalimat (29) merupakan salah satu ciri dari bahasa lisan yang ditandai dengan kalimat bahasa lisan kurang terstruktur.

Penggunaan struktur kalimat.

Ragam Bahasa lisan: Kursi panas, siapa cepat dia dapat. (Wibowo)

Ragam Bahasa tulis: Dia mendapat kursi panas (Wibowo)

Dalam ragam bahasa tulis unsurunsur fungsi gramatikal seperti subjek, predikat dan objek harus lebih terstruktur. Kalimat (29) kalimatnya lebih terstruktur jika unsur kalimat $S$ P O nya disusun dengan baik. Dia sebagai subjek, mendapat sebagai predikat dan kursi panas sebagai objek.

Kalimat yang terstruktur adalah:

Ragam Bahasa tulis: Dia mendapat kursi panas. (Wibowo)

\section{b. Variasi Bahasa Lisan tidak Baku}

a) Penggunaan Bahasa Daerah

Salah satu penanda penggunaan bahasa lisan tidak baku adalah penggunaan bahasa daerah. Penggunaan bahasa daerah ditandai dengan penggunaan akhiran o pada akhir kata dalam kolom Mela Komentar.

Data adalah sebagai berikut.

Data 07

Tabel 4/Data 07/RB/01112016/:

Sebanyak 8417 unit kendaraan dinas di 10 Pemda kabupaten/kota menunggak pajak.
Berdasarkan dataBadan Pemeriksa Keuangan (BPK), tunggakan pajak ribuan kendaraan dinas tersebut mencapai $\operatorname{Rp~6,3}$ miliar. (Topik 07)

\section{Kalimat:}

(46) Berarti kami dak usah bayar pajak kendaraan jugo cik. Pemerintah bae cak itu. Kalu duit untuk bayar pajaknyo lah masuk ke perut. (Ujang)

Kalimat (46) termasuk dalam variasi bahasa lisan tidak baku. Salah satu ciri dari variasi bahasa lisan tidak baku adalah penggunaan bahasa daerah. Kalimat terdiri atas empat kata bahasa daerah, yaitu bae, cak, kalu dan pajaknyo. Penggunaan kata bae merupakan padanan kata dari saja dalam bahasa Indonesia. Penggunaan kata cak merupakan padanan kata dari seperti. Penggunaan kata kalu merupakan padanan kata dari kalau. Penggunaan kata pajaknyo merupakan padanan kata dari pajaknya dalam bahasa Indonesia.

b) Penggunaan Kata tidak Baku

Salah satu penanda penggunaan bahasa lisan tidak baku adalah penggunaan kata tidak baku. Penggunaan kata tidak baku ditemui dalam kolom Mela Komentar.Data adalah sebagai berikut.

\section{Data 06}

Tabel 4/Data 06/RB/31112016/:

Susah Cari Isi Ulang Gas Melon Wajar cik kalau kito susah nyari isi ulang tabung gas melon. Ruponyo memang penyaluran tabung isi ulang dari pangkalan ke pengecer memang distop. Bisa ditebak cik, selain susah dicari harga isi ulang gas melon jadi tinggi. (Topik 06)

\section{Kalimat:}

(41) Yo lah min, ndak masar kan tabung semangko yang baru th na 5,5 kg non subsidi. (Midian)

Kalimat (41) termasuk dalam variasi bahasa lisan tidak baku. Salah satu ciri dari variasi bahasa lisan tidak baku adalah penggunaan kata tidak baku. Kalimat 
terdiri atas satu kata tidak baku, yaitu masar. Penggunaan kata masar seharusnya adalah jual jika ditambahkan imbuhan meakan menjadi kata baku yaitu menjual.

Selain penggunaan kata tidak baku, pada kalimat juga di temukan penggunaan kosa kata bahasa daerah dilihat pada yaitu kata yo, ndak dan semangko. Penggunaan kosa kata bahasa daerah pada kata yo merupakan padanan kata ya. Dalam kosa kata bahasa Indonesia kata ya, artinya adalah kata untuk menyatakan setuju. Penggunaan kosa kata bahasa daerah pada kata ndak merupakan padanan dari kata mau. Kata semangko merupakan padanan dari kata semangka dalam bahasa Indonesia.

\section{c) Penggunaan Bahasa Gaul}

Salah satu penanda penggunaan bahasa lisan tidak baku adalah penggunaan bahasa gaul. Penggunaan bahasa gaul ditandai dengan melepaskan bunyi, perpaduan vokal dan mengalami pengenduran vokal dalam kolom Mela Komentar.

Data adalah sebagai berikut.

\section{Data 14}

\section{Tabel 4/Data 14/RB/08112016/:}

Anjloknya prestasi olahraga Bengkulu beberapa tahun terakhir, diklaim oleh pelaku olahraga lantaran minimnya sarana dan prasarana yang ada. Ini berpengaruh pada prestasi yang didapat. Kondisi ini perlu segera diatas, mengingat Bengkulu juga akan menjadi tuan rumah Pekan Olahraga Wilayah Sumatera 2018. (Topik 14)

\section{Kalimat:}

(114) Cukup intropeksi masing-masing aja. (Adit)

Kalimat (114) termasuk dalam variasi bahasa lisan tidak baku. Salah satu ciri dari variasi bahasa lisan tidak baku adalah penggunaan bahasa gaul. Kalimat terdiri atas bahasa gaul yaitu aja. Penggunaan kosa kata bahasa gaul aja melepaskan segmen pertama setelah didahului bunyi vokal seperti Ruas /s/ yang menjadi pengawal sehingga saja menjadi aja. Selain penggunaan bahasa gaul, penggunaan kata tidak baku dapat dilihat pada kata intropeksi. Penggunaan kata intropeksi seharusnya adalah introspeksi yang artinya mengoreksi kesalahan atau kekurangan diri sendiri.

\section{d) Pernyataan Ekspresi}

Salah satu penanda penggunaan bahasa lisan tidak baku adalah pernyataan ekspresi. Pernyataan ekspresi ditandai dengan penggunaan kata hahaha dalam kolom Mela Komentar.

Data adalah sebagai berikut.

\section{Data 08}

Tabel 4/Data 08/RB/02112016/:

Rencana Pemerintah Provinsi Bengkulu menaikkan gaji tenaga honorer tahun 2017, batal. Tenaga honorer yang diperpanjang kontraknya diberikan diskon jam kerja. Dalam seminggu hanya bekerja tiga hari. (Topik 08)

\section{Kalimat:}

(57) Tigo hari di dinas sini, tigo hari di dinas sano, dak ketahuan, kan enak gajinyo duo cik, hahah (Apri)

Kalimat (57) termasuk dalam variasi bahasa lisan tidak baku. Salah satu ciri dari variasi bahasa lisan tidak baku adalah pernyataan ekspresi. Kalimat terdiri atas satu kata ekspresi, yaitu hahahaha. Penggunaan kata hahahaha merupakan mengungkapan perasaan lucu dan ketidak seriusan dalam memberikan komentar. Selain penggunaan pernyataan ekspresi, penggunaan kata tidak baku dapat dilihat pada kata dak kemudian kemudian penggunaan kosa kata bahasa daerah pada kata tigo, sano, gajinyo dan duo.

Penggunaan kata dak telah merupakan padanan kata tidak. Penggunaan kata tigo merupakan padanan kata tiga. Penggunaan kata sano merupakan padanan kata sana. 
Penggunaan kata duo telah mengalami padanan kata dua.

\section{Variasi bahasa dalam kolom Mela Komentar surat kabar Rakyat Bengkulu dilihat dari segi keformalannya.}

a) Ragam Santai

Ciri penanda ragam santai adalah: (1) penggunaan unsur bahasa asing atau daerah, (2) penggunaan kata tidak baku, (3) penggunaan bahasa gaul, (4) adanya pernyataan ekspresi.

\section{a. Penggunaan Bahasa Daerah}

Salah satu penanda penggunaan ragam santai adalah penggunaan bahasa daerah. Penggunaan bahasa daerah ditandai dengan penggunaan akhiran o pada akhir kata dalam kolom Mela Komentar.

Data adalah sebagai berikut.

Data 11

Tabel 6/Data 11/RB/05112016/:

Selepas salat Jumat, ribuan masyarakat Bengkulu turun ke jalan. Aksi damai di Simpang Lima mendesak aparat hukum menindak dugaan penistaan agama. (Topik 11)

Kalimat:

(80) Siapo yang melakukan penistaan agama tuh? Kyai kanjeng yang bisa gandakana duit tuh? (Djong)

Kalimat (80) termasuk dalam variasi bahasa dari segi keformalan berupa ragam santai. Salah satu ciri dari ragam santai adalah penggunaan bahasa daerah. Kalimat terdiri atas dua kata bahasa daerah, yaitu siapo dan gandakana. Penggunaan kata siapo merupakan padanan dari kata siapa dalam bahasa Indonesia, artinya untuk menanyakan. Kata gandakana merupakan padanan kata gandakanlah dalam bahasa Indonesia, yang artinya memperbanyak.

Selain penggunaan bahasa daerah, adanya penggunaan kosa kata tidak baku pada yaitu kata tu dan duit dengan digunakan kosa kata tidak baku. Kata tu merupakan padanan dari kata itu dalam bahasa Indonesia. Kata duit merupakan padanan kata uang dalam bahasa Indonesia.

\section{b. Penggunaan Kata tidak Baku}

Salah satu penanda ragam santai adalah penggunaan kata tidak baku. Penggunaan kata tidak baku ditemui dalam kolom Mela Komentar.

Data adalah sebagai berikut.

\section{Data 12}

\section{Tabel 6/Data 12/RB/06112016/:}

PLN Tertibkan Pelanggan Listrik 900 VA Nah cik, mulai Januari 2017 subsid listrik 900 Vadicabut. Akibatnyo ada kenaikan 32 persen bagi pelanggan biasa. Kecuali bagi warga yang memilki surat sakti dengan data Tim Nasional Percepatan Penanggulanagan Kemisinan (TNP2K) alias pemegang KKS, KIS dan PKH. Rencananyo PLN akan melakukan penertiban pelanggan yang mengunakan listrik 900 VA. Cemano itu cik? (Topik 12)

\section{Kalimat:}

(93) Waii naik 32\%, lumayan juga nambahnya. (Rahmat)

Kalimat (93) termasuk dalam variasi bahasa dari segi keformalan berupa ragam santai. Salah satu ciri dari ragam santai adalah penggunaan kata tidak baku. Kalimat terdiri atas dua kata tidak baku, yaitu nambahnya. Penggunaan kata nambahnya digunakan kata tidak baku, kata nambahnya merupakan padanan dari kata tambah. Penggunaan kata nambah seharusnya adalah imbuhan ber- kemudian kata tambah menjadi bertambah.

\section{c. Pernyataan Ekspresi}

Salah satu penanda penggunaan ragam santai adalah pernyataan ekspresi heheheh. Pernyataan ekspresi ditemui dalam kolom Mela Komentar. Data adalah sebagai berikut.

Data 13

Tabel 6/Data 13/RB/07112016/: 
BCP tolak Mundur dari Gub DKI. Nah cik, setelah demo besar-besaran memang Kapolri janji akan menuntaskan kasus dugaan penistaan agama oleh Gubernur DKI, BCP non aktif secepatnya. Nah terbaru dia malah minta dipenjara. Dia menolak mundur dari pencalonan Gubernur DKI. (Topik 13)

\section{Kalimat:}

(104) Bukan masalah Islam atau Ahok, tetapi kesalahan redaksional mantan jurnalis lulusan Amerika yang lupa bahasa Indonesia. Hehheheh (Anto)

Kalimat (104) termasuk dalam variasi bahasa dari segi keformalan berupa ragam santai. Salah satu ciri dari ragam santai adalah pernyataan ekspresi. Kalimat terdiri atas satu kata ekspresi, yaitu hehehehe. Penggunaan kata heheheh merupakan ketidak seriusan dalam memberikan komentar.

Kalimat (104) memberikan komentar tentang setelah demo besar-besaran memang Kapolri janji akan menuntaskan kasus dugaan penistaan agama oleh Gubernur DKI, BCP non aktif secepatnya. Nah terbaru dia malah minta dipenjara. Dia menolak mundur dari pencalonan Gubernur DKI.

\section{d. Bahasa Gaul}

Salah satu penanda penggunaan ragam santai adalah penggunaan bahasa gaul. Penggunaan bahasa gaul ditandai dengan melepaskan bunyi, perpaduan vokal dan mengalami pengenduran vokal dalam kolom Mela Komentar.

Data adalah sebagai berikut.

Data 23

\section{Tabel 6/Data 23/RB/17112016/:}

Harapan masyarakat ingin segera memiliki Kartu Tanda Penduduk elektronik (e-KTP) tidak bisa terwujud dalam waktu dekat. Pasalnya, Ditjend Kementerian Dalam Negeri (Kemendagri) baru akan melakukan lelang blangko e-KTP pada Januari 2017 mendatang. (Topik 23)

\section{Kalimat:}

(194) Yang sabar aja. Anggaran tahun ini dah habis jadi anggaran tahun depan lagi. Pake surat keterangan domisili aja dulu dak (Adit)

Kalimat (194) termasuk dalam variasi bahasa dari segi keformalan berupa ragam santai. Salah satu ciri dari ragam santai adalah penggunaan bahasa gaul. Kalimat terdiri atas bahasa gaul yaitu pake dan aja. Penggunaan kosa kata bahasa gaul pake terjadi karena perpaduan vokal. Proses ini hampir mirip dengan proses persandian karena berpadunya dua vokal menjadi bunyi vokal yang baru. Dalam bahasa pergaulan remaja ada beberapa kata yang mengandung proses perpaduan vokal. Kata /pakai/ menjadi [pake] karena Bunyi [ai] dalam bahasa Indonesia berubah menjadi bunyi [e] dalam bahasa pergaulan remaja. Penggunaan kosa kata bahasa gaul aja melepaskan segmen pertama setelah didahului bunyi vokal seperti ruas /s/ yang menjadi pengawal sehingga saja menjadi aja.

\section{b) Ragam Akrab}

Ciri penanda ragam akrab adalah: (1) penggunaan kata sapaan, penggunakan bahasa asing atau daerah, (3) penggunakan istilah-istilah khas.

\section{a. Penggunaan Kata Sapaan}

Kata sapaan sebagai kata ganti, data penggunaan kata sapaan sebagai kata ganti yaitu kata ganti saya, kami dan dio (padanan kata dia dalam bahasa Indonesia).

\section{Data 03}

\section{Tabel 8/Data 16/RB/10112016/:}

Angka tunggakan pelanggan PT. PLN (Persero) wilayah S2JB Area Bengkulu cukup tinggi. Per 26 Oktober 2016 saja, jumlah saldo tunggakan RP 16, 24 miliar dari 58 ribu pelanggan.

Kalimat: 
(24) Saya bayar terus bos, ngak pernah yang namanya telat, sadar dirilah (Kharis)

Kalimat (24) termasuk dalam variasi bahasa dari segi keformalan berupa ragam akrab. Salah satu ciri dari ragam akrab adalah penggunaan kata sapaan. Kalimat terdiri atas kata sapaan, yaitu saya. Kata saya digunakan sebagai kata ganti dari orang yang berbicara. Adanya data kata sapaan menandakan bahwa ragam yang digunakan dalam memberikan pendapat digunakan ragam akrab.

\section{b. Penggunaan Bahasa Daerah}

Salah satu penanda penggunaan ragam akrab adalah penggunaan bahasa daerah. Penggunaan bahasa daerah ditandai dengan penggunaan akhiran o pada akhir kata dalam kolom Mela Komentar.

Data adalah sebagai berikut.

\section{Data 05}

\section{Tabel 8/Data 05/RB/30102016/:}

Korban penipuan SN, ibu artis ibukota asal Bengkulu, terus bertambah. Sebelumnya, SN dilaporkan dua korban, Agustina dan Yanti karena uang mereka $\mathrm{Rp} 350$ juta tidak dikembalikan. Kali ini korbannya adalah Wati (54) istri pengacara kondang, Drs. Ahmad Nurdin, SH. Cak mano ini cik. (Topik 05)

\section{Kalimat:}

(32) Usut tuntas biar jelas, kalu piti emang sensitif nian cik. (Deri)

Kalimat (32) termasuk dalam variasi bahasa dari segi keformalan berupa ragam akrab. Salah satu ciri dari ragam akrab adalah penggunaan bahasa daerah. Kalimat terdiri memaki bahasa daerah, yaitu kata piti. Penggunaan kata piti merupakan padanan kata dari uang dalam bahasa Indonesia. Selain penggunaan kata bahasa daerah, penggunaan kata sapaan dapat dilihat pada kata cik. Penggunaan kata cik merupakan panggilan untuk seorang kakak perempuan maupun laki-laki. Kalimat (32) memberikan komentar bahwa kalau sudah membahas uang jangan sampai salahsalah.

\section{c. Penggunaan Istilah Khas.}

Salah satu penanda penggunaan ragam akrab adalah penggunaan istilah khas. Penggunaan istilah khas ditemui dalam kolom Mela Komentar.

Data adalah sebagai berikut.

\section{Data02}

Tabel 8/Data 2/RB/27102016/:

Hampir dipastikan terhitung 1 Januari 2017, gaji honorer akan dianggarkan minimal sesuai Upah Minimum Provinsi (UMP). Seperti diketahui UMP tahun 2017 yang bakal ditetapkan gubernur Rp 1,7 juta. (Topik 2)

Kalimat:

(7) Semoga idak di PHP kan cik. (Feri)

Kalimat (7) termasuk dalam variasi bahasa dari segi keformalan berupa ragam akrab. Salah satu ciri dari ragam akrab adalah penggunaan istilah khas. Kalimat terdiri atas satu kata istilah khas, yaitu PHP. Penggunaan kata PHP digunakan singkatan, singkatan merupakan hasil pemendekan yang berupa huruf atau gabungan huruf baik yang dieja huruf maupun yang tidak dieja huruf demi huruf. Penggunaan kata PHP merupakan singkatan dari pemberi harapan palsu.

Selain digunakan istilah khas, adanya penggunaan kosa kata bahasa daerah dapat dilihat pada kata cak, kecik dan seharusnyo. Kata cak merupakan padanan dari dari kata seperti dalam bahasa Indonesia. Kata kecik merupakan padanan dari kata kecil dalam bahasa Indonesia. Kata seharusnyo merupakan padanan kata seharusnya dalam bahasa Indonesia.

\section{KESIMPULAN}

Berdasarkan hasil penelitian dan pembahasan tentang variasi bahasa dalam kolom Mela Komentar surat kabar Rakyat Bengkulu, maka dapat disimpulkan sebagai berikut. 
1. Variasi bahasa dalam kolom Mela Komentar surat kabar Rakyat Bengkulu ketika menyampaikan ide, pendapat dan gagasannya terhadap topik yang dibicarakan adanya penggunaan variasi bahasa lisan, yaitu variasi bahasa lisan baku dan variasi bahasa lisan tidak baku. Penggunaan bahasa lisan baku ditandai dengan penggunaan bentuk kata, pelesapan unsur kata, unsur-unsur gramatikal tidak selalu dinyatakan dan penggunaan struktur kalimat. Dikatakan baku karena adanya penggunaan kosa kata dan diksi bahasa Indonesia, tidak menggunakan bahasa asing atau bahasa daerah. Penggunaan variasi bahasa lisan tidak baku ditandai dengan unsur-unsur bahasa daerah, penggunaan kata tidak baku dan penggunaan bahasa gaul.

2. Variasi bahasa dilihat dari segi keformalan dalam kolom Mela Komentar surat kabar Rakyat Bengkulu ketika menyampaikan ide, pendapat dan gagasannya terhadap topik yang dibicarakan adanya penggunaan variasi bahasa, yaitu ragam santai dan ragam akrab. Penggunaan ragam santai ditandai dengan penggunaan bahasa asing atau bahasa daerah, penggunaan kata tidak baku, penggunaan bahasa gaul dan pernyataan ekspresi. Penggunaan ragam akrab ditandai dengan penggunaan kata sapaan, penggunaan bahasa asing atau daerah dan istilah-istilah khas.

\section{DAFTAR PUSTAKA}

Chaer, A. \& Agustina. 2010. Sosiolingustik Perkenalan Awal. Jakarta: Rineka Cipta.

Wijaya, P. D. \& Muhammad R. 2013. Sosiolinguistik. Yogyakarta: Pustaka Pelajar.

Sudaryanto. 1988. Metode Lingustik Bagian Pertama Ke Arah Metode Lingustik. Yogyakarta: Gadjah Mada University Press

Sugiyono. 2012. Metode Penelitian Pendidikan Pendekatan Kuantitatif, Kualitatif, dan $R$ \& D. Yogyakarta: Alfabeta.

Sumarsono. $2004 . \quad$ Sosiolingustik. Yogyakarta: Sabda. 